\title{
Food and Feeding Habits of Grey Mullets (Pisces: Mugilidae) in Two Estuaries in Ghana
}

\author{
H. R. Dankwa ${ }^{1 *}$, J. Blay Jr², K. Yankson ${ }^{2}$ \\ ${ }^{1}$ CSIR-Water Research Institute, P. O. Box 38, Achimota, Ghana \\ ${ }^{2}$ University of Cape Coast, Cape Coast, Ghana \\ *Corresponding author, E-mail: hrdankwa@hotmail.com
}

\begin{abstract}
Food and feeding habits of grey mullets (Mugilidae) in the River Volta and River Pra estuaries in Ghana were studied between February 1997 and July 1998 as part of efforts to encourage their culture. Stomach contents of fish samples, obtained with a cast net and a drag net, were analysed using the 'points' and frequency of occurrence method. Diatoms, detrital material and sand particles were the major items in the stomachs of all the species from the two estuaries. Their diet did not show any substantial seasonality, neither did it change with size. The various species ingested sand particles of selected range with Liza dumerilii ingesting the widest range in both estuaries, 41.2-1195.8 $\mu$ m in the Volta estuary, and 33.0-1649.0 $\mu \mathrm{m}$ in the Pra estuary. Species that ingested the same modal size of sand particles showed preferences for different food items. The shortest mean relative gut length (gut length to body length ratio) of 1.82 and 1.72 were calculated for $L$. dumerilii in the Volta and Pra estuaries, respectively, while the longest mean relative gut length of 4.56 was calculated for Mugil cephalus in the Volta estuary and 4.33 for Liza grandisquamis in the Pra estuary. All the species showed a diurnal feeding habit, with the main feeding period occurring between 08.00 and $12.00 \mathrm{~h}$. The peak feeding time, however, differed among the species.
\end{abstract}

\section{Introduction}

Grey mullets contribute substantially to the fishery of tropical and subtropical regions of the world (Wijeyaratne \& Costa, 1986; Koutrakis, Sinis \& Economidis,1994). Subsequently, they are a major source of subsistence protein requirements of the peoples of many countries (ICLARM, 1980), including Ghana. Their characteristics, including the ability to grow to a large size and ready availability, have made the group an excellent choice for culture (Bardach, Ryther \& Mclarney,1972). For a successful culture operation of any species, however, a good understanding of the biology of the species is an important pre-requisite. Food and feeding habits of grey mullets have, therefore, been a major research area (Marais, 1980; Ferrari \& Chieregato, 1981; Albaret \& Legendre, 1985; Blaber, 1987; King, 1988; Ikomi, 1990).

The only work done in Ghana on food and feeding habits of grey mullets is by Blay $(1995 a, b)$ in the Elmina and Cape Coast lagoons. Thus, information on the food and feeding habits of grey mullets in Ghana, especially from estuarine ecosystems and the offshore marine waters, is limited. This study was undertaken as part of efforts to encourage the culture of grey mullets in Ghana to enhance local fish production.

\section{Materials and methods}

The study was conducted at the estuaries of River Pra and River Volta, both of which discharge into the Gulf of Guinea (Fig. 1). The River Volta estuary lies within the coastal savanna zone with an annual rainfall of 750-1,250 mm (Dickson \& Benneh, 1977). The estuary is about $1.2 \mathrm{~km}$ wide at the mouth. Two dams have been built on the River Volta at Akosombo and further down at Kpong, and these, to a large extent, influence the quality and quantity of water at the estuary. 


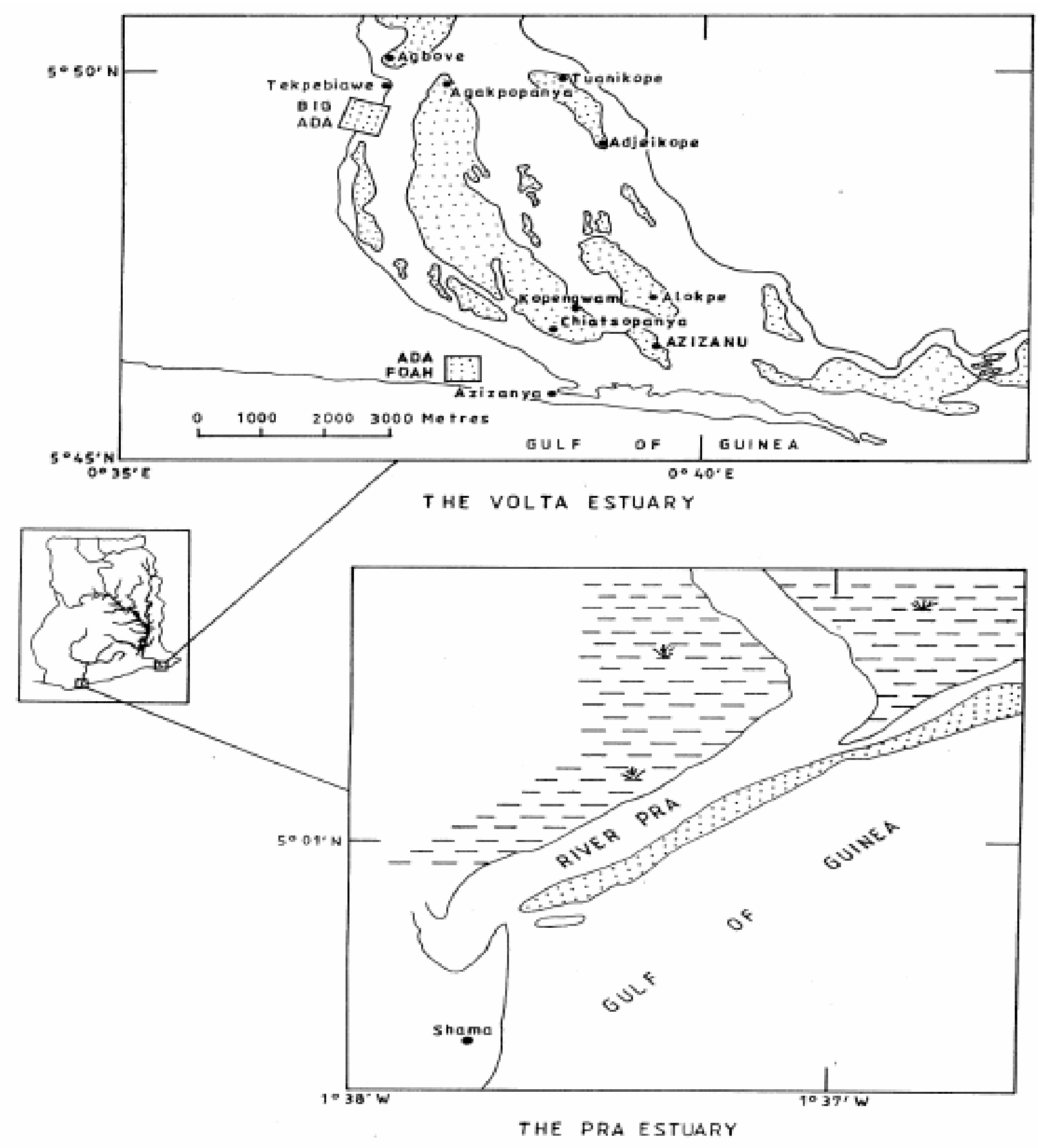

Fig. 1. Map of Ghana showing the location of the Volta and Pra estuaries

The River Pra basin lies in the moist evergreen forest zone of Ghana, with an annual rainfall of between 1,500 and 1,750 mm (Dickson \& Benneh, 1977). Its banks, unlike the Volta estuary, where most of the banks are settlements, are fringed by red mangroves (Rhizophora spp.) up to about $10 \mathrm{~km}$ inland (Obodai, Yankson \& Blay Jr, 1996). The estuary is approximately $100 \mathrm{~m}$ wide at the point of entry into the sea and the basin is subjected to impacts of mining activities upriver.

Grey mullets were sampled from the estuaries each month from February 1997 to July 1998. The fish were caught with a cast net and a drag net. Samples were also obtained from the catches of local fishermen to augment the experimental catches. Two 24-h samplings were undertaken during the periods 11-12 November 1998 and 9-10 June 1999 in the Volta estuary to determine the daily feeding periodicity. Sampling was done at four-hourly intervals with a seine net. Two hauls were made at each sampling time, both of which lasted about $80 \mathrm{~min}$. Conditions in the Pra estuary precluded the use of a dragnet, which was the only means of collecting sufficient samples for studies on the daily feeding cycle.

Mullet samples were kept in 10\% formalin and later sorted out into the various species using identification keys (Schneider, 1990; Lévêque, Paugy \& Teugels, 1992). The total length (TL) and standard length (SL) of the fish were measured to the nearest $1.0 \mathrm{~mm}$ and weighed to the nearest $0.1 \mathrm{~g}$. The stomach contents of each individual were also 
weighed to the nearest $0.01 \mathrm{~g}$ and the total length of the intestine measured to the nearest $1.0 \mathrm{~mm}$ to calculate the relative gut length.

In each month, between five and 10 stomachs of each species were preserved in $5 \%$ formalin. Points were awarded each stomach according to its degree of fullness using an arbitrary 4-point scale (20, 15, 10 and 5 points for full, 3/4, 1/2 and $1 / 4$ filled stomach, respectively). The food items were identified under high power objectives of the microscope. Further analysis of the stomach contents was carried out to assess the percentage composition and frequency of occurrence of the food items (Hynes, 1950).

The stomach contents were broadly grouped into polychaetes, zooplankton, diatoms, green algae, blue-green algae, detritus and sand particles. Using a calibrated eyepiece micrometer, random measurements were made of the longest axis of sand particles from stomachs of the grey mullet species to determine particle size preference among species and between sites. The Stomach Fullness Index (FI) was used as an indicator of feeding intensity to evaluate seasonal feeding activity as well as diel feeding periodicity of the various species. It was calculated using the equation:

$\mathrm{FI}=($ Weight of stomach contents $\times 100) / \quad$ Fish weight $($ Hureau, 1966).

Samples used for the calculation of FI were those captured between $8.00 \mathrm{~h}$ and $11.00 \mathrm{~h}$ since that was the most active period for feeding. A cluster analysis was performed to illustrate similarities among the species based on the frequency of stomach contents.

Size range

\section{Results}

The size range of the different species of grey mullets in the two estuaries is presented in Table 1. Bigger specimens of each species were caught in the Volta estuary than in the Pra estuary.

TABLE 1

Size range of grey mullets caught in the Volta and Pra estuaries

\begin{tabular}{|c|c|c|c|c|}
\hline \multirow[t]{2}{*}{ Species } & \multicolumn{3}{|c|}{ Volta estuary } & \multirow{2}{*}{$\begin{array}{l}\text { Pra estuary } \\
\text { Wt (g) }\end{array}$} \\
\hline & $\mathrm{SL}(\mathrm{mm})$ & Wt (g) & $\mathrm{SL}(\mathrm{mm})$ & \\
\hline L. falcipinnis & $38-239$ & $1.1-262.3$ & $42-217$ & $1.3-205.6$ \\
\hline L. dumerilii & $45-233$ & $1.6-216.3$ & $47-230$ & $2.3-238.7$ \\
\hline L. grandisquamis & - & $70-163$ & 7.9-104.8 & \\
\hline M. bananensis & $54-195$ & 3.6-174.5 & 47-193 & $2.1-153.2$ \\
\hline M. curema & $54-270$ & $3.6-444.1$ & $50-158$ & $3.4-78-4$ \\
\hline M. cephalus & $77-570$ & $10.2-3300$ & $115-355$ & $34.8-1250$ \\
\hline
\end{tabular}

- $\quad$ Absent

\section{Composition of stomach contents}

Apart from fish scales and eggs that were found in the stomachs of L. falcipinnis and an unidentified species of red alga found in a few stomachs of L. grandisquamis and M. bananensis from the Pra estuary, all the other items were common in the stomachs of all the species from the two estuaries. Twelve species of diatoms, 12 of green algae and 10 species of blue-green algae were identified (Table 2). The most common diatoms found in the stomachs were species of Navicula, Surirella, Synedra, Gyro-sigma, Nitzschia, and Cyclo-tella. The blue-green algae consumed consisted mainly of filamentous types (e.g. Lyngbya spp., Oscilla-toria spp. and Anabaena spp.) and unicellular forms (e.g. Merismopedia sp.), while the green algae were mostly species of desmids and filamentous types (e.g. Chaetophora sp., and Ulothrix sp.). Copepods and protozoans (mainly foramini-ferans) were the dominant zooplankton in the diet. 


$\begin{array}{ll}\text { Stomach contents } & \text { Stomach contents } \\ \text { Bacteria } & \text { Blue-green algae } \\ \text { Benthic organisms } & \text { Spirulina sp. } \\ \text { Polychaetes } & \text { Chroococcus sp. } \\ \text { Nematodes } & \text { Lyngbya sp. } \\ \text { Zooplankton } & \text { Anabaena sp. } \\ \text { Annelid larvae } & \text { Oscillatoria sp. } \\ \text { Crustacean larvae } & \text { Merismepodia sp. } \\ \text { Protozoans } & \text { Microcystis sp. } \\ \text { Dinoflagellates } & \text { Calothrix sp. } \\ \text { Copepods } & \text { Agmellum sp. } \\ \text { Ostracods } & \text { Gomphosphaeria sp. } \\ \text { Rotifers } & \text { Green algae } \\ \text { Cladocerans } & \text { Closterium sp. } \\ \text { Diatoms } & \text { Pediastrum sp. } \\ \text { Surirella } \text { sp. } & \text { Staurastrum sp. } \\ \text { Gyrosigma sp. } & \text { Ankistrodesmus sp. } \\ \text { Navicula sp. } & \text { Schizomeris sp. } \\ \text { Nitzschia sp. } & \text { Chaetophora sp. } \\ \text { Synedra sp. } & \text { Spirogyra sp. } \\ \text { Stephanodiscus sp. } & \text { Ulothrix sp. } \\ \text { Cyclotella sp. } & \text { Microspora sp. } \\ \text { Gomphonema sp } & \text { Prasiola } \\ \text { Pinnularia sp. } & \text { Stichococcus sp. } \\ \text { Diatoma sp. } & \text { Scenedesmus sp. } \\ \text { Melosira sp. } & \text { Unidentified filamentous green algae } \\ \text { Cymbella sp. } & \text { Red algae } \\ \text { Sand particles } & \text { Fish scales } \\ \text { Detritus } & \text { Fish eggs } \\ & \\ & \end{array}$

Data on stomach contents from the monthly samples were pooled to assess their overall composition in the various species (Fig. 2). This was done after it had been ascertained that there was no appreciable change in the stomach contents throughout the seasons and also among the various size groups of a given species. Bacteria, nematodes, red algae and other organisms as well as fish scales, whose composition in the diet was less than 1.0\%, were not included in the analysis. Benthic organisms were, therefore, made up of only polychaetes. Sand particles, diatoms, detritus and green algae were the most important food items, with sand particles forming the bulk of the diet of all the species from both estuaries. Polychaetes also formed an important component of the diet of M. cephalus from both estuaries. 

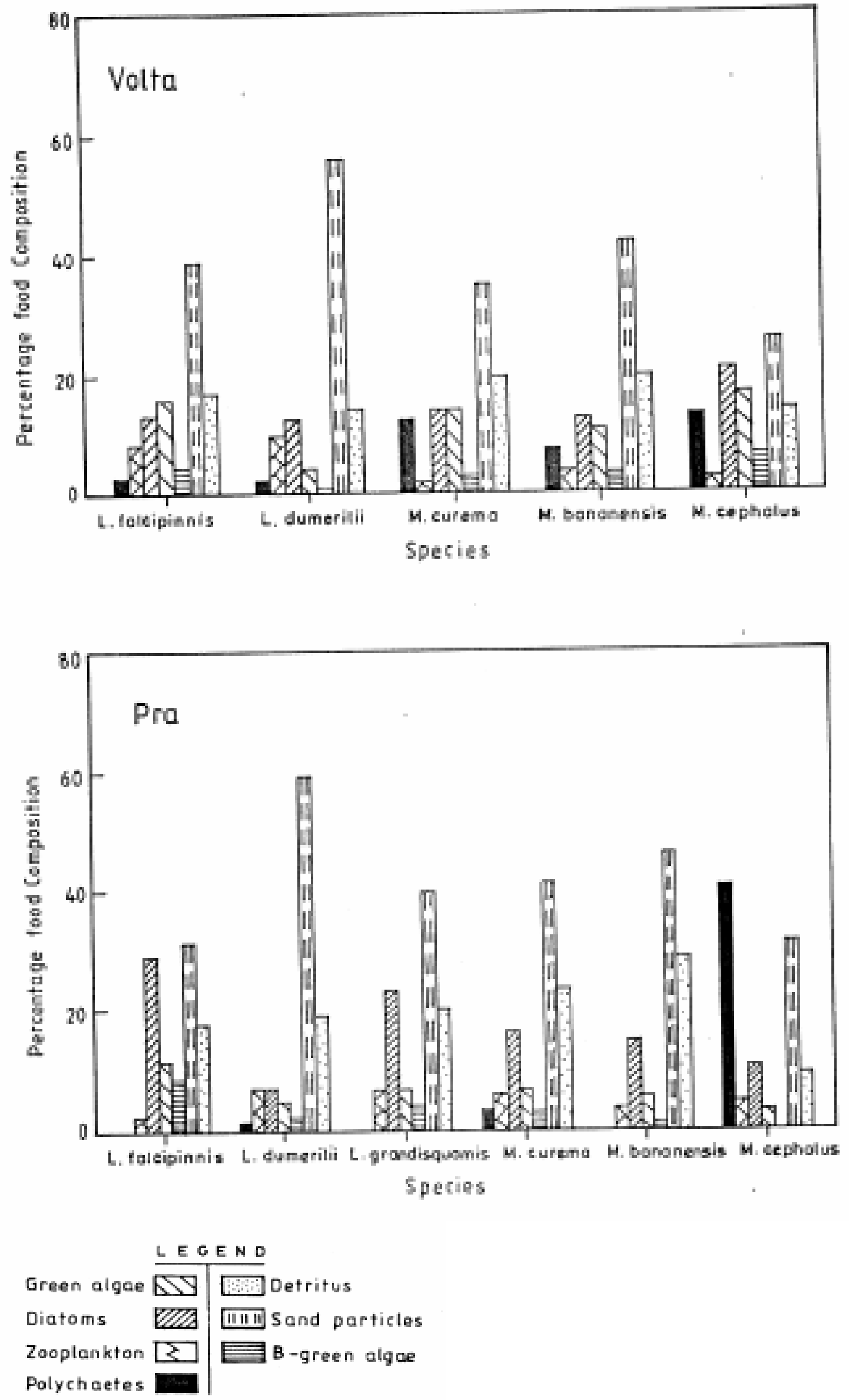

Fig. 2. Composition of stomach contents of grey mullets from the Volta and Pra estuaries 
Cluster dendograms (Fig. 3), based on frequency of items consumed by the different species in each estuary, show that L. falcipinnis and M. bananensis frequently consumed similar items in both estuaries. Also, L. dumerilii and $L$. grandisquamis ate similar items in the Pra estuary. The items found in the stomachs of $M$. curema in the two estuaries were more related to that found in L. falcipinnis and $M$. bananensis in both places and also to that found in the stomachs of $L$. dumerilii and L. grandisquamis in the Pra estuary. M. cephalus in the two estuaries had little interaction with the other species with respect to the items found in their stomachs. This is, most probably, due to the presence of more polychaetes in their stomachs compared to the other species. 

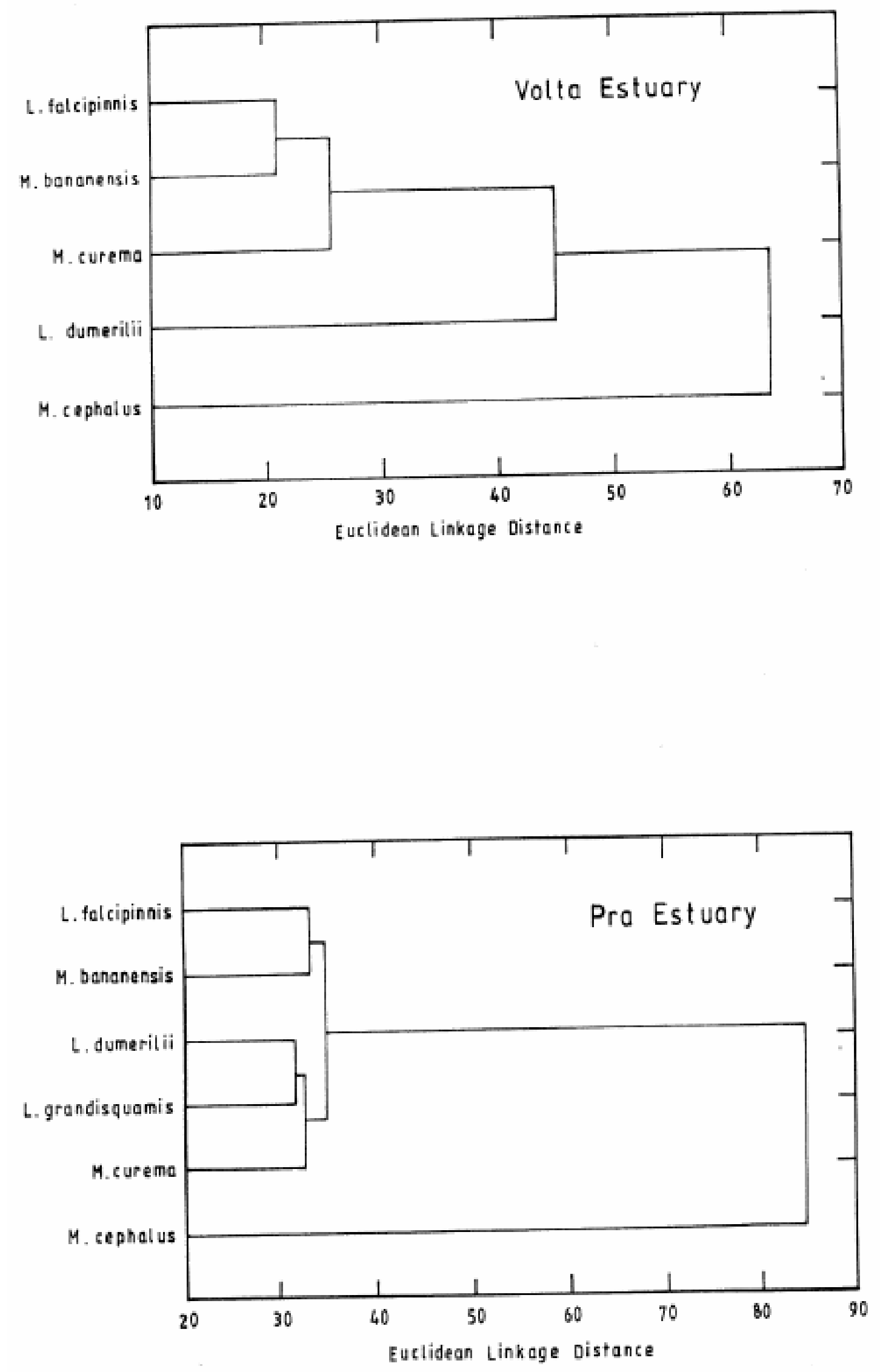

Particle size selection

Species from the Volta estuary generally ingested larger sand particles than their counterparts from the Pra estuary (Table 3). In each estuary, L. dumerilii ingested the widest range of sand particles from 41.2 to $1195.8 \mu \mathrm{m}$ with a mean size of $248.8 \mu \mathrm{m}$ in the Volta estuary, and from 33.0 to $1649 \mu \mathrm{m}$ with a mean size of $194.6 \mu \mathrm{m}$ in the Pra estuary. The most frequently ingested sand particles by L. dumerilii, M. curema and M. cephalus in the Volta estuary 
measured 120-139 $\mu \mathrm{m}$. In the Pra estuary, the most selected particle size by $L$. dumerilii was 80-99 $\mu$ m, similar to the commonest size ingested by L. grandisquamis in the same estuary. The size of sand particles filtered by the latter species, however, ranged from 31.4 to $270.4 \mu \mathrm{m}$. The smallest size range of 16.5-255.7 $\mu \mathrm{m}$ was ingested by $M$. bananensis in the Pra estuary while in the Volta estuary, $L$. falcipinnis filtered the smallest size range, 33.0-479.4 $\mu \mathrm{m}$. The most ingested particle size ranged from 40 to $59 \mu \mathrm{m}$ for $M$. bananensis, and from 80 to $99 \mu \mathrm{m}$ for L. falcipinnis.

TABLE 3

Size of sand particles ingested by grey mullets from the Volta and Pra estuaries

\begin{tabular}{|c|c|c|c|c|}
\hline Species & Estuary & $\begin{array}{l}\text { Particle size } \\
\text { range }(\mu \mathrm{m})\end{array}$ & $\begin{array}{l}\text { Modal class } \\
(\mu \mathrm{m})\end{array}$ & $\begin{array}{l}\text { Mean particle dia } \\
\text { meter } \pm S . E(\mu m)\end{array}$ \\
\hline \multirow[t]{2}{*}{ L. falcipinnis } & Volta & $33.0-479.4$ & $60-79$ & $126.7 \pm 5.8$ \\
\hline & Pra & $31.2-479.4$ & $40-59$ & $118.3 \pm 6.0$ \\
\hline \multirow[t]{2}{*}{ L. dumerilii } & Volta & $41.2-1195.8$ & $120-139$ & $248.8 \pm 13.7$ \\
\hline & Pra & $33.0-1649.4$ & $80-99$ & $194.6 \pm 12.9$ \\
\hline \multirow[t]{2}{*}{ L. grandisquamis } & Volta & & & \\
\hline & Pra & $-31.2-270.4$ & $-80-99$ & $-99.7 \pm 3.7$ \\
\hline \multirow[t]{2}{*}{ M. bananensis } & Volta & $41.2-494.8$ & $80-99$ & $132.9 \pm 6.4$ \\
\hline & Pra & $16.5-255.7$ & $40-59$ & $71.9 \pm 3.5$ \\
\hline \multirow[t]{2}{*}{ M. curema } & Volta & $33.0-618.6$ & 120-139 & $156.5 \pm 6.6$ \\
\hline & Pra & $31.2-527.8$ & $60-79$ & $123.1 \pm 6.1$ \\
\hline \multirow[t]{2}{*}{ M. cephalus } & Volta & $41.2-783.5$ & $120-139$ & $213.3 \pm 9.7$ \\
\hline & Pra & $31.2-675.4$ & $100-119$ & $187.3 \pm 7.0$ \\
\hline
\end{tabular}

\section{Daily feeding cycle}

Changes in the mean index of stomach fullness of the mullets in the Volta estuary over two 24-h periods are illustrated in Fig. 4. The main feeding period in the Volta estuary was during the day between $08.00 \mathrm{~h}$ and $12.00 \mathrm{~h}$ for all the species. There was little or no feeding during the night, except for $M$. cephalus for which feeding activity peaked at $20.00 \mathrm{~h}$ during the first 24-h sampling. The peak in feeding activity for L. dumerilii and L. falcipinnis occurred at $08.00 \mathrm{~h}$ while the peak for $M$. bananensis and $M$. curema occurred at $12.00 \mathrm{~h}$ on both sampling occasions. The highest feeding activity on both occasions was shown by L. dumerilii which consumed 2.3 and $2.6 \%$ of its body weight of food while $M$. cephalus was the least active feeder. 

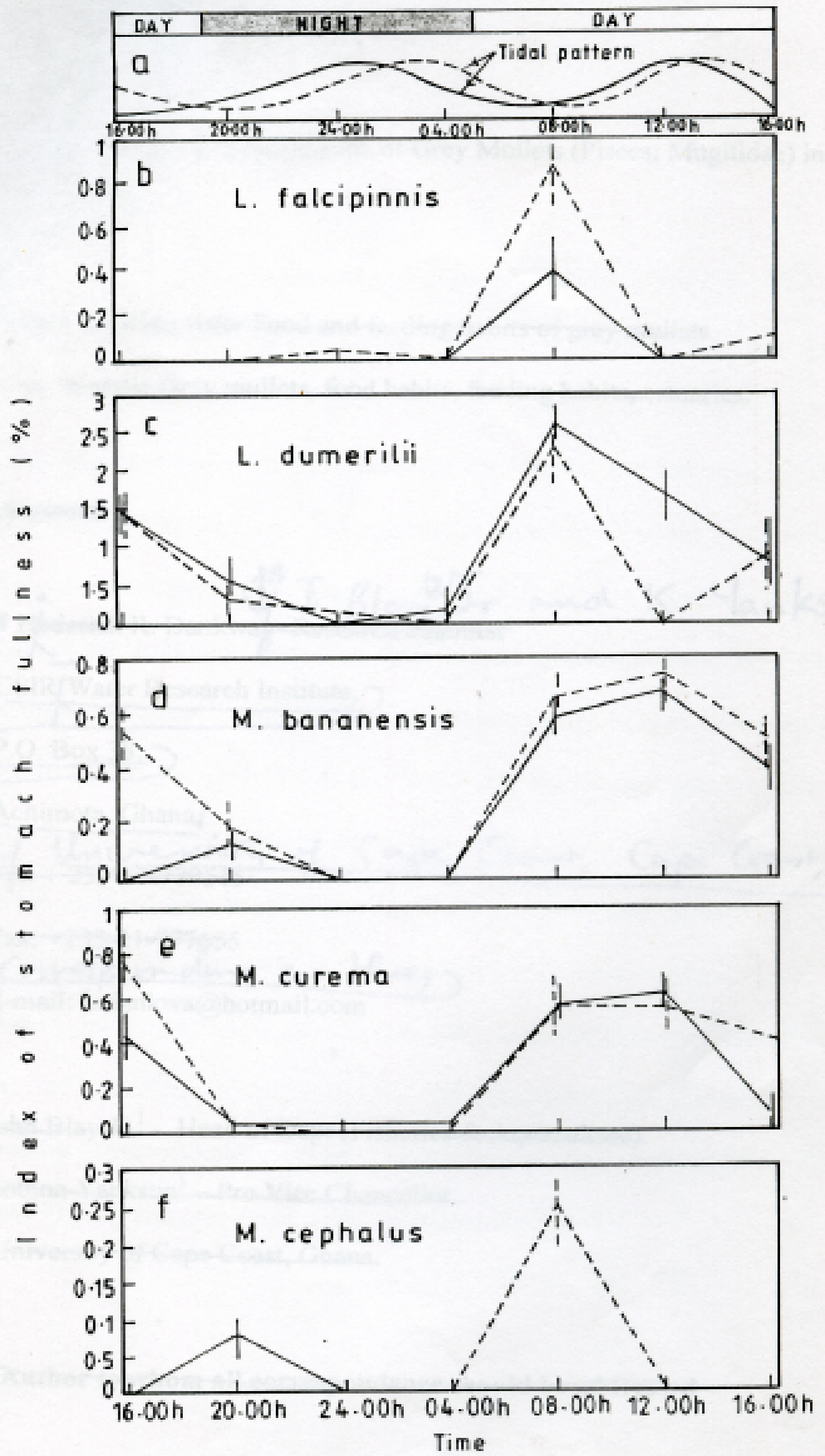

Fig. 4. Tidal pattern and feeding periodicity of grey mullets in the Volta estuary during 11-12 November 1998 (- ) and 9-10 June 1999 (-). Vertical bars $= \pm \mathrm{SE}$ 
The least mean ratio of the length of the intestine to standard length of fish (relative gut length) was 1.82 and 1.72 for L. dumerilii in the Volta and Pra estuaries, respectively. M. cephalus in the Volta estuary had the highest ratio (4.56) while in the Pra estuary the longest relative gut length of 4.33 was calculated for L. falcipinnis (Table 4). The relative gut length of $M$. cephalus in the Pra estuary was not determined because of its low sample size. To compare the relative gut lengths of a given species from the two sites, a Student's $t$-test was performed (Sokal \& Rohlf, 1981). The relative gut length of $L$. falcipinnis and $L$. dumerilii in the Volta estuary was significantly different $(p<0.05)$ from specimens in the Pra estuary. However, those of $M$. bananensis and M. curema in the Volta estuary were fairly similar to their counterparts in the Pra estuary.

TABLE 4

Relative gut length and standard length of grey mullets from the Volta and Pra estuaries

\begin{tabular}{|c|c|c|c|c|c|}
\hline \multirow[t]{2}{*}{ Species } & \multirow{2}{*}{$\begin{array}{l}\text { Number of } \\
\text { specimens } \\
\text { analysed }\end{array}$} & \multirow{2}{*}{$\begin{array}{l}\text { Range of } \\
\text { standard } \\
\text { length } \\
(\mathrm{mm})\end{array}$} & \multirow{2}{*}{$\begin{array}{l}\text { Range of } \\
\text { gut } \\
\text { length } \\
(\mathrm{mm})\end{array}$} & \multicolumn{2}{|c|}{ Relative qut length } \\
\hline & & & & Range & Mean \pm S.E. \\
\hline \multicolumn{6}{|l|}{ Volta estuary } \\
\hline L. falcipinnis & 106 & $125-232$ & 270-1054 & $2.00-4.59$ & $3.89 \pm 0.07$ \\
\hline L. dumerilii & 102 & $65-200$ & $120-415$ & $1.18-2.57$ & $1.82 \pm 0.03$ \\
\hline M. bananensis & 78 & $62-190$ & $162-820$ & $2.61-5.07$ & $3.76 \pm 0.08$ \\
\hline M. curema & 124 & $87-235$ & 265-1475 & $2.48-5.59$ & $3.96 \pm 0.05$ \\
\hline M. cephalus & 32 & $113-375$ & 380-1565 & $3.36-5.27$ & $4.56 \pm 0.10$ \\
\hline \multicolumn{6}{|l|}{ Pra estuary } \\
\hline L. falcipinnis & 143 & $70-120$ & $230-580$ & $2.95-5.92$ & $4.33 \pm 0.06$ \\
\hline L. dumerilii & 92 & $60-168$ & $88-370$ & $1.36-2.50$ & $1.72 \pm 0.03$ \\
\hline L. grandisquamis & 63 & $80-160$ & $105-390$ & $1.08-2.56$ & $2.00 \pm 0.06$ \\
\hline M. bananensis & 88 & $75-170$ & $160-600$ & $2.67-4.58$ & $3.81 \pm 0.05$ \\
\hline M. curema & 104 & $70-113$ & $170-505$ & $2.46-5.05$ & $4.01 \pm 0.05$ \\
\hline
\end{tabular}

\section{Discussion}

The diet of all the species in the two estuaries was similar, but slight variations in proportions of food items were noted. The food consisted mostly of diatoms, algae, detrital material and sand particles. Polychaetes were also prominent, especially in the diet of $M$. cephalus. The diet of the mullets examined in this study does not differ appreciably from that of species studied elsewhere in West Africa (Fagade \& Olaniyan, 1973; King, 1988; Bruhlet, 1975; Payne, 1976; Albaret \& Legendre, 1985) where mullets have been reported to feed mainly on diatoms, organic detritus and sand grains. Although the nutritional value of detritus may be negligible, it is considered a good source of vitamin B $_{12}$ for mullets (Vallet et al., 1970 quoted in Eggold \& Motta, 1992) and is also richly associated with bacteria and protozoa which may be of some nutritional value to the fish (Bruslé, 1981).

Even though sand particles occurred in the stomachs of all the species, they were predominant in the stomachs of $L$. dumerilii, forming $61 \%$ and $57 \%$ of the stomach contents in the Volta and Pra estuaries, respectively. Ingested sand particles are supposedly helpful in the grinding of food particles in the thick-walled pyloric stomach, which acts as a gizzard (Thomson, 1966). Apart from the 'grinding' action, sand particles with the associated micro-organisms serve as a source of nutrition (Hickling, 1970; Odum, 1970).

It has been suggested that grey mullets ingest sand particles of a selected range (Odum, 1968). This was evident in this study where it was found that the different species in each estuary selected different size ranges of sand particles, with $L$. dumerilii selecting the widest range in both estuaries. The particle size consumed by each species varied according to locality, probably due to differences in the substrate in each estuary. Ingestion of larger particles by $L$. dumerilii compared to other mugilids has been reported by Masson \& Marais (1975) from the Zwartkops estuary in Cape Province in South Africa, Payne (1976) from the Black Johnson estuary in Sierra Leone and Blay (1995a) from the Elmina lagoon in Ghana.

Even though $L$. dumerilii ingested the widest range of sand particles, the size it preferred most was also ingested by $M$. curema and M. cephalus in the Volta estuary, and by L. grandisquamis in the Pra estuary. In the former estuary, $L$. dumerilii showed a preference for zooplankton and diatoms while $M$. cephalus and $M$. curema ingested less zooplankton but more of green algae and polychaetes. In the Pra estuary, L. grandisquamis ingested more of diatoms while polychaetes and zooplankton were prominent in the diet of L. dumerilii. Thus, species that ingested similar modal sizes of sand particles showed preferences for different food items. This corroborates the findings of Blaber (1976) who noted differences in the food of L. dumerilii and M. cephalus although they selected similar sand 
particles. It would also appear from the results of this study that species that ingested finer particles consumed more plant material and organic matter, while those that ingested coarser particles showed preference for substrates rich in animal material.

According to Nilson (1967), when two closely-related species coexist in one environment, various mechanisms may occur which permit this coexistence. One of these is the partitioning of resources. The preference of each grey mullet species in the two estuaries for a particular particle size was a way of partitioning the resource to avoid interspecific competition, thus ensuring their coexistence.

Apart from detritus and sand particles, results on food habits from the current study confirms the findings of Blay (1995a) who reported on the diet of juveniles of four mullet species (L. falcipinnis, L. dumerilii, M. curema and M. bananensis) from the Elmina lagoon in Ghana. Comparatively, mullets in the Elmina lagoon utilize a wider range of food items than was found in the current study. The composition of the diet of grey mullets from different localities is likely to differ, depending on the abundance and types of food organisms present (Blaber, 1977; Bruslé, 1981). The wide range of food items of mugilids has also been reported by Cain \& Dean (1976) who explained that such flexibility in feeding ensures a constant energy supply for the sustenance of the population.

The herbivorous feeding habit of adult mullets outside the West African sub-region have been reported by Blaber (1977), De Silva \& Wijeyaratne (1977), Whitfield \& Blaber (1978), Marais (1980) and Minckley (1982). The ecological importance of such a diet has been recognized by Odum (1970), who considered mullets as important in providing the herbivore link in the food chain in estuaries and shallow coastal waters. Their low position in the food chain is also an asset in pond culture because production of their preferred food items can easily be enhanced in ponds through inexpensive methods of fertilization.

All the species in the Volta estuary showed a marked temporal feeding pattern during a 24-h period with higher feeding activity during the day (08.00-12.00 h) and very little or no feeding activity during the night $(20.00-04.00 \mathrm{~h})$. Thus, the species showed a diurnal feeding habit as reported in lagoons at Elmina and Cape Coast in Ghana (Blay, 1995 a,b). Studies by other researchers, e.g. Blabber (1976) on L. macrolepis from the St Lucia Lake system in South Africa, De Silva \& Wijeyaratne (1977) on M. cephalus from the Negombo Lagoon in Sri Lanka and Collins (1981) on M. cephalus from Florida showed that these species fed little at night.

Diurnal feeding activity of the mullets in this study was most probably influenced by photoperiodicity, as noted by Keast \& Welsh (1968) for many other fishes. Apart from this, other factors, e.g. tides and salinity, have been cited to influence feeding intensity in mugilids (Marais, 1980; Almeida et al., 1993) and Odum (1970) reported a higher feeding intensity in mullets at high tide. No such relationship was, however, found for species in the Elmina lagoon (Blay, 1995a). In the present study, tides apart from photoperiodicity may have influenced the feeding activity of $L$. falcipinnis, L. dumerilii and M. cephalus with high feeding intensity at low tides. There was, however, no definite relationship between tides and the feeding activity of $M$. bananensis and $M$. curema.

Peak feeding activity of the fishes occurred about the same time in both experimental periods. Differences, however, occurred in the peak feeding time among the species. Different mugilid species have been reported to feed at different times (Marais, 1980; Drake, Arias \& Gallegos, 1984). Differences in the peak feeding time among the grey mullet species in the Volta estuary could be one of the probable mechanisms for avoiding competition as suggested by Blaber (1976) for sympatric mullets.

Apart from L. dumerilii from both estuaries and L. grandisquamis whose relative gut length ranged from 1.72 to 2.0, all the other species had higher relative gut lengths of between 3.7 and 4.5. Results of the present study show that populations with a higher relative gut length tended to consume more plant material, as shown by L. falcipinnis and M. curema and also reported by Hickling (1970) and Collins (1981). Longer guts could be an adaptation to increasing the digestive area and ensure that such food items are properly digested. The higher consumption of zooplankton by $L$. dumerilii and L. grandisquamis may be related to their smaller relative gut length, although diatoms were also major food items.

\section{Conclusion}

Stomach contents of grey mullets in the two estuaries consisted of mainly diatoms, detrital material and sand particles. They showed a marked temporal feeding pattern with high feeding activity during the day. The peak of feeding time and the size of sand particles filtered differed among the species. Those found to ingest the same modal size of sand particles showed preference for different food items. These could be strategies adopted to avoid interspecific competition and ensure their coexistence. Their low position in the food chain is an asset in pond culture because production of their preferred food items can easily be enhanced in ponds through inexpensive methods of fertilization.

\section{Acknowledgement}

The authors are grateful to the National Agricultural Research Programme (NARP) which provided funding for this study. They are also grateful to Water Research Institute of the Council for Scientific and Industrial Research and the Zoology Department of the University of Cape Coast for providing the necessary logistic support. 


\section{References}

Albaret J-J. and Legendre M. (1985). Bioliogie et ecologie des Mugilidae en lagune Ébrié (Côte d'Ivoire) Intérêt potentiel pour l'aquaculture lagunaire. Revenue d'Hydrobiologie Tropical 18(4): 281-304.

Almeida P. R., Moreira F., Costa J. L., Assis C. A. \& Costa M. J. (1993). The feeding strategies of L. ramanda (Risso, 1826) in fresh and brackish water in the River Tagus, Portugal. J. Fish Biol. 42: 95-107.

Bardach J. E., Ryther J. H. and Mclarney W. O. (1972). Aquaculture: The farming and husbandry of freshwater and marine organisms. New York, Wiley Interscience. 868 pp.

Blaber S. J. M. (1987). Factors affecting recruitment and survival of mugilids in estuaries and coastal waters of Southern Africa. Am. Fish. Soc. Symp. 1: 507-518.

Blaber S. J. M. (1977). The feeding ecology and relative abundance of mullet (Mugilidae) in Natal and Pondoland estuaries. Biol. J. Linn. Soc. 9: 259-275.

Blaber S. J. M. (1976). The food and feeding ecology of Mugilidae in the St. Lucia Lake system. Biol. J. Linn. Soc. 8: $267-227$.

Blay J. Jr. (1995a). Food and feeding habits of four species of juvenile mullets (Mugilidae) in a tidal lagoon in Ghana. J. Fish Biol. 46: 134-141

Blay J. Jr. (1995b). Food habits and diel feeding periodicity of juvenile sicklefin mullet, Liza falcipinnis (Pisces: Mugilidae), in a 'closed' tropical lagoon. Arch. Hydrobiol. 135 (2): 271-281.

Bruhlet J. (1975). Observations on the biology of Mugil cephalus ashenteensis and the possibility of its culture on the Mauritanian coast. Aquaculture 5: 271-281.

Bruslé J. (1981). Food and feeding in grey mullets. In Aquaculture of the grey mullets (O.H. Oren, ed.). Cambridge Univ. Press. pp. 185-217.

Cain R. L. and Dean J. M. (1976). Annual occurrence, abundance and diversity of fish in a south Carolina intertidal creek. Mar. Biol. 36: 369-379.

Collins M. R. (1981). The feeding periodicity of striped mullet, Mugil cephalus L. in two Florida habitats. J. Fish Biol. 19: 307-315.

De Silva S. S. and Wijeyaratne M. J. S. (1977). Studies on the biology of young mullet, Mugil cephalus, L. II. Food and feeding. Aquaculture 12: 157-167.

Dickson B. K. and Benneh G. (1977). A new geography of Ghana. London: Longman Group Ltd. 173 pp.

Drake P. Arias A. M. and Gallegos L. (1984). Biologia de los Mugilidos (Osteichthyes, Mugilidae) en los esteros de las salinas de San Fernanda (Cadiz). III. Habitos alimentarias y su relaction con la morfometria del aparatdigestivo. Investigciones Pesqueras 48: 337-367.

Eggold B. T. and Motta P. J. (1992). Ontogenetic dietary shifts and morphological correlates in striped mullet, Mugil cephalus. Envir. Biol. Fishes 34 (2): 139-158.

Fagade S. O. and Olaniyan C. I. O. (1973). The food and feeding interrelationships of the fishes in the Lagos Lagoon. J. Fish Biol. 5: 205-225.

Ferrari I. and Chieregato A. R. (1981). Feeding habits of juvenile stages of Sparus auratus L., Decentrachus labrax L. and Mugilidae in a brackish embayment of the Po river delta. Aquaculture 25 (2-3): 243-257.

Hickling C. F. (1970). A contribution to the natural history of the English grey mullets (Pisces, Mugilidae). J. Mar. Biol. Assoc. U.K. 50: 609-633.

Hureau J. C. (1966). Biologie comparée de quelques poissons antartique (Nototheniidae). Bull. Inst. Oceanogr. Monaco 68: 1-244.

Hynes H. B. N. (1950). The food of fresh water sticklebacks (Gasterosteus aculeatus and Pygosteus pungitius) with a review of methods used in studies of the food of fishes. J. Anim. Ecol. 19: 36-58.

International Centre for Aquatic Resources Management (ICLARM) (1980). Introduction. In Review of breeding and propagation techniques for grey mullet, Mugil cephalus L. (C.E. Nash and Z.H. Shehadeh, ed.). ICLARM Studies and Reviews 3. 87 pp.

Ikomi R. B. (1990). On the ecology of the grey mullet (Mugil cephalus L.) in Kulama Creek (Niger Delta, Nigeria). Acta Hydrobiol. 32 (1/2): 237-249.

Keast A. and Welsh L. (1968). Daily feeding periodicities, food uptake rates and dietary changes with hour of day in some lake fishes. J. Fish. Res. B. Can. 25: 1133-1144.

King R. P. (1988). New observations on the trophic ecology of Liza grandisquamis (Valenciennes, 1836) (Pisces: Mugilidae) in the Bonny river, Niger Delta, Nigeria. Cybium 12 (1): 23-36.

Koutrakis E. T., Sinis A. I. and Economidis P. S. (1994). Seasonal occurrence, abundance and size distribution of grey mullet fry (Pisces: Mugilidae) in the Porto-Lagos lagoon and Lake Vistonis (Aegaean Sea, Greece). Bamidgeh 46 (4): 182-196.

Lévèque C., Paugy D. and Teugels G. G. (1992). Faune des poissons d'eauxouces et sumatres de l'Afrique de l'Ouest (Tome 2). Collection Faune Tropical no. XXVIII. ORSTOM et MARC. 
Masson H. and Marais J. F. K. (1975). Stomach content analyses of mullets from the Zwartkops estuary. Zoologica Afr. 10: 193-207.

Marais J. F. K. (1980). Aspects of food intake, food selection and alimentary canal morphology of Mugil cephalus L. Liza tricuspidens Smith, L. richardsoni Smith and L. dumerili Steindachner. J. exp. mar. Biol. Ecol. 44: 193210.

Minckley W. L. (1982). Trophic interrelations among introduced fishes in the lower Colorado River, Southeastern U.S., Calif. Fish Game 68: 78-89.

Nilson N. A. (1967). Interactive segregation between fish species. In The Biological basis of freshwater fish production (S. D. Gerking, ed.), pp. 295-313. Oxford: Blackwell Scientific Publications.

Obodai E. A., Yankson K. and Blay J. Jr. (1996). Seasonal changes in hydrographic factors and breeding in two populations of Crassostrea tulipa (Lamarck). Ghana J. Sci. 31-36 (1991-1996): 45-51.

Odum W. E. (1970). Utilisation of the direct grazing plant and detritus food chains by the striped mullet, Mugil cephalus. In: Marine food chains. (J.H. Steele, ed.), pp. 220-240. London: Oliver and Boyd..

Odum W. E. (1968). Ecological significance of fine particle selection by the striped mullet, Mugil cephalus L. Limnol. Oceanogr. 13: 92-98.

Payne A. L. (1976). The relative abundance and feeding habits of the grey mullet species occurring in an estuary in Sierra Leone, West Africa. Mar. Biol. 35: 277-286.

Schneider W. (1990). Field guide to the commercial marine resources of the Gulf of Guinea. FAO, Rome. RAFR/FI/90/2.

Sokal R. R. and Rohlf F. J. (1981). Biometery: The principles and practices of statistics in biological research. San Francisco: W.H. Freeman and Company. 859 pp.

Thomson J. M. (1966). The grey mullets. Oceanogr. Mar. Biol. 4: 301-335.

Whitfield A. K. and Blaber S. J. (1978). Resource aggregation among illiophagous fish in St. Lucia, Zululand. Envi. Biol. Fish 3: 293-296.

Wijeyaratne M. J. S. and Costa H. H. (1986). On the biology of an estuarine population of grey mullet, Mugil cephalus L. in Negambo lagoon, Sri Lanka. Cybium 10: 351-363. 